\title{
ANALISIS PERBANDINGAN KEUNTUNGAN DAN RISIKO AGRIBISNIS RUMPUT LAUT (Eucheuma cottonii) DENGAN MENGGUNAKAN TEKNIK BUDIDAYA DAN ALAT PUKAT DI KELURAHAN PANTAI AMAL KOTA TARAKAN
}

\author{
Anang Sulistyo ${ }^{1}$,Titin Wahyuni ${ }^{1}$ \\ ${ }^{1}$ Program Studi Agribisnis, Fakultas Pertanian, Universitas Borneo Tarakan, \\ Email: anangtyo@borneo.ac.id
}

Diterima: 15 Agustus 2020

Disetujui: 26 September 2020

\begin{abstract}
The seaweed business in the Pantai Amal Village was carried out using two techniques, namely cultivation and trawler techniques. Each technique had different risks and contributions to the profits of farmers because the production inputs used were also different. This study aimed to: (I) analyze and compare the costs, revenues, and profits of seaweed farming by cultivation and trawler techniques; (2) analyze and compare the risks of the two seaweed farming techniques. Number of respondents was determined using the Slovin method and selection of respondents was done using a purposive sampling method. The amount of costs, revenues, and profits were analyzed using profit analysis and level of business risk was measured using a coefiicient of variation (CV) analysis tool. The results showed that the costs, receipts, and profits of seaweed farming using trawl techniques were greater than that of seaweed farming with cultivation techniques, with the costs $R p$ 20,834,936, and $R p$ l1,445,627 respectively, the receipts Rp41,996,212 and Rp15,018,181 respectively, and the profits Rp21,152,276 and Rp3,572,555 respectively. Trawl seaweed business had lower cost and profit risks than cultivation seaweed business, with a variation coefficient value $(C V)$ respectively 0.02 and 0.03 . The risk of seaweed farming using trawl and cultivation techniques was the same, namely 0.05. The profit risk of using cultivation techniques was higher than using trawling techniques, namely 0.15 and 0.09, respectively.
\end{abstract}

Keywords: Profit, Business Risk, Seaweed Business

\begin{abstract}
ABSTRAK
Usaha rumput laut di Kelurahan Pantai Amal terdiri dari dua teknik yaitu teknik budidaya dan alat pukat. Masing-masing teknik memiliki risiko dan kontribusi yang berbeda dalam keuntungan petani dikarenakan input produksi yang digunakan juga berbeda-beda. Penelitian ini bertujuan untuk: (1)Menganalisis dan membandingan biaya, penerimaan, dan keuntungan usaha rumput laut teknik budidaya dan alat pukat 2) Menganalisis dan membandingan risiko usaha rumput laut teknik budidaya dan alat pukat. Penentuan jumlah responden menggunakan metode Slovin dan pemilihan responden dengan metode purposive sampling. Besarnya biaya, penerimaan, dan keuntungan di analisis dengan analisis keuntungan sedangkan untuk mengukur tingkat risiko usaha menggunakan alat analisis koefisien variasi (CV). Hasil penelitian menunjukkan bahwa biaya, penerimaan, dan keuntungan usahatani rumput laut teknik alat pukat lebih besar dibandingkan dengan usahatani rumput laut teknik budidaya dengan biaya masing-masing sebesar $\mathrm{Rp}$ 20.834.936 dan Rp 11.445.627 penerimaan masing-masing sebesar Rp 41.996.212 dan Rp 15.018.181, sedangkan keuntungan masing-masing sebesar Rp 21.152.276 dan Rp 3.572.555. Usaha rumput laut teknik pukat memiliki risiko biaya dan risiko keuntungan lebih rendah dibandingkan dengan usaha rumput laut teknik budidaya dengan besar nilai koefisien variasi (CV) masing-masing sebesar 0,02 dan 0,03, risiko penerimaan usahatani rumput laut teknik pukat dan teknik budidaya sama yaitu 0,05 , untuk risiko keuntungan usaha rumput laut teknik budidaya lebih tinggi dari pada teknik pukat yaitu masing-masing 0,15 dan 0,09.
\end{abstract}

Kata Kunci : Keuntungan, Risiko Usaha, Usaha Rumput Laut 


\section{PENDAHULUAN}

Rumput laut atau lebih dikenal dengan sebutan sea weed merupakan sumber daya hayati yang sangat melimpah di perairan Indonesia. Rumput laut merupakan salah satu komoditas penting hasil perikanan yang memiliki nilai ekonomis, dan merupakan salah satu sumber devisa negara. Keanekaragaman rumput laut di Indonesia merupakan yang terbesar dibandingkan dengan negara lain (Rahim, 2018).

Kalimantan Utara merupakan salah satu provinsi yang memiliki kawasan perikanan yang cukup luas, salah satunya yaitu Tarakan. Saat ini, daerah yang memiliki rumput laut di perairan Tarakan yaitu Pantai Amal, Tanjung Karis, Selumit Pantai Lingkas Ujung, Karang Rejo Pantai, Tanjung Pasir, dan Tanjung Batu. (Ardiansyah, Nurjannatul 2019).

Kelurahan Pantai Amal yang merupakan kawasan pesisir tidak hanya berpotensi dalam sektor pariwisata tetapi juga berpotensi dalam pemanfaatan rumput laut dalam jumlah yang besar. Di daerah ini, mayoritas penduduk bermata pencaharian sebagai petani rumput laut dimana dalam kegiatannya terdapat dua teknik yaitu teknik budidaya dan penjaringan rumput laut dengan alat pukat.

Dalam teknik pembudidayaan rumput laut, daerah operasi pembudidayaan sudah ditentukan secara pasti dan faktor-faktor produksi yang digunakan juga berbeda dengan teknik pukat. Dalam pembudidayaannya, produksi akan menurun jika terkena penyakit, gelombang besar, dan umur rumput laut yang terlalu lama sehingga rumput laut menjadi rontok, sehingga nelayan akan mendapatkan hasil yang tidak sesuai. Namun ketika hal tersebut terjadi, para petani yang menjaring rumput laut kemungkinan akan menguntungkan mereka karena rumput laut yang rontok tadi dapat tertampung dijaring mereka, sehingga menimbulkan peningkatan hasil produksi.

Berdasarkan hal tersebut, sebagian besar nelayan rumput laut meningkatkan pendapatan mereka dalam membudidayakan rumput laut dan penjaringan dengan alat pukat. Dari masingmasing teknik tersebut memberikan kontribusi yang berbeda dalam pendapatan atau keuntungan masing-masing petani rumput laut. Dikarenakan input produksi yang digunakan juga berbedabeda. Oleh karena itu diperlukan analisis perbandingan keuntungan dan resiko usaha yang dapat memperlihatkan tingkat keuntungan dan resiko masing-masing teknik usaha rumput laut, sehingga memperoleh informasi bagi wirausahawan kedepannya mengenai usaha rumput laut.

Tujuan dari penulisan artikel ilmiah ini adalah Menganalisis dan membandingkan biaya, penerimaan, dan keuntungan usaha rumput laut teknik budidaya dan alat pukat di Kelurahan Pantai Amal serta Menganalisis dan membandingkan risiko usaha rumput laut teknik budidaya dan alat pukat di Kelurahan Pantai Amal.

\section{METODE}

\section{Tempat dan Waktu Penelitian}

Penelitian ini dilakukan di Kelurahan Pantai Amal, Kecamatan Tarakan Timur, Kota Tarakan yang merupakan kawasan penghasil rumput laut. Penelitian ini dilaksanakan pada bulan November 2019 sampai dengan bulan Mei tahun 2020.

\section{Metode Penentuan Sampel}

Jumlah populasi dalam penelitian ini adalah seluruh petani yang membudidayakan dan menjaring rumput laut dengan alat pukat di Kelurahan Pantai amal berjumlah 195 petani. Dalam penelitian ini, penulis mempersempit populasi dengan menghitung ukuran sampel yang dilakukan menggunakan teknik Slovin menurut Sugiyono (2011).

Berdasarkan perhitungan sampel yang mejadi responden dalam penelitian ini dengan presentase kelonggaran yang digunakan adalah $10 \%$, di sesuaikan menjadi 66 responden, dimana 33 petani yang menggunakan teknik budidaya dan 33 petani yang menggunakan alat pukat. Penetapan sampel dalam penelitian ini menggunakan metode purposive sampling, yaitu petani yang menggunakan teknik budidaya dengan ciri-ciri :

1. Membudidayakan rumput laut.

2. Pengalaman usahatani minimal 1 tahun

dan teknik alat pukat dengan ciri-ciri sebagai berikut :

1. Petani menggunakan teknik alat pukat

2. Pengalaman usahatani minimal 1 tahun

\section{Jenis dan Sumber Data}

Data yang dikumpulkan dalam penelitian ini terdiri atas dua jenis yaitu:

1. Data primer yang diperoleh dari hasil penarikan sampel, dimana variabel yang diamati adalah keadaan umum pembudidaya dan pemukat rumput laut,biaya tetap, biaya variabel, penerimaan dan pendapatan pembudidaya, dan resiko usaha. 
2. Data sekunder yang diperoleh dari instansi terkait yang berhubungan dengan penelitian yaitu Kantor Kelurahan Pantai Amal, Dinas Perikanan Kota Tarakan, dan instansi yang terkait.

\section{Metode Pengumpulan Data}

Teknik pengumpulan data yang digunakan dalam penelitian ini adalah sebagai berikut:

1. Teknik wawancara yaitu teknik pengumpulan informasi dari responden dengan menggunakan kuisioner.

2. Teknik kepustakaan yaitu pengumpulan data dengan mencermati buku-buku teks atau literatur-literatur, jurnal-jurnal penelitian dan bahan-bahan lainnya yang relevan sebagai landasan teori dalam penelitian ini.

\section{Analisis Data}

\section{1) Analisis biaya dan Keuntungan}

Menurut Suratiyah (2006), keuntungan merupakan selisih antara total penerimaan dengan total biaya eksplisit dan implisit yang dikeluarkan. Dengan rumus:

1. Biaya

$$
\mathrm{TC}=\mathrm{TFC}+\mathrm{TVC}
$$

2. Penerimaan

3. Keuntungan

$$
\mathrm{TR}=\mathrm{Y} . \mathrm{Py}
$$

$$
\begin{aligned}
& \pi=\text { TR- } \mathrm{TC}_{\mathrm{E}+\mathrm{I}} \\
& \pi=\mathrm{TR}-(\mathrm{TVC}+\mathrm{TFC})_{\mathrm{E}+1} \\
& \pi=\text { Py.Y-(Px.X+TFC) })_{\mathrm{E}+1} \\
& \text { Keterangan: } \\
& \pi \quad=\text { Keuntungan } \\
& \text { TR = Penerimaan Total } \\
& \mathrm{TC}_{\mathrm{E}+\mathrm{I}}=\text { Biaya Total }_{\text {Eksplisit+Implisit }} \\
& \text { TFC = Biaya Tetap Total } \\
& \text { TVC = Biaya Variabel Total } \\
& \text { Py = Harga Output } \\
& \mathrm{Y}=\text { Jumlah Input } \\
& \mathrm{Px}=\text { Harga Input } \\
& \mathrm{X}=\text { Jumlah Input }
\end{aligned}
$$

Kriteria pengambilan keputusan yaitu:

a. Jika TR > TC, maka usaha rumput laut teknik budidaya atau alat pukat menguntungkan.

b. Jika TR < TC, maka usaha rumput laut teknik budidaya atau alat pukat rugi.

c. $\quad$ Jika $\mathrm{TR}=\mathrm{TC}$, maka usaha budidaya rumput laut atau alat pukat dalam keadaan Break Event Point atau tidak untung dan tidak rugi.
Untuk mengetahui perbedaan antara teknik rumput laut budidaya dan alat pukat di Kelurahan Pantai Amal, maka dilakukan uji komparasi dengan menggunakan uji statistik menggunakan distribusi z (Hasan, 2008). Prosedur pengujian hipotesisnya sebagai berikut:

a. Menentukan hipotesis yang akan diuji, yaitu: Ho : $\mu \mathrm{p}=\mu \mathrm{m}$, artinya biaya, penerimaan, keuntungan dan risiko usaha rumput laut teknik budidaya tidak terdapat perbedaan nyata dengan biaya, penerimaan, keuntungan dan risiko usaha rumput laut dengan teknik menggunakan alat pukat .

Ha : $\mu \mathrm{p} \neq \mu \mathrm{m}$, artinya biaya, penerimaan, keuntungan resiko usaha rumput laut dengan teknik budidaya terdapat perbedaan nyata dari biaya, penerimaan, keuntungan dan risiko usaha rumput laut dengan teknik menggunakan alat pukat.

b. Menentukan nilai z tabel.

c. Mencari nilai $\mathrm{z}$ hitung dengan formula sebagai berikut (Hasan, 2008).

$$
\bar{Z}=\frac{\bar{X} 1-\bar{X} 2}{S * 1-x^{2}}
$$

Dengan

$$
\sigma \times 1-x \overline{2}=\sqrt{\frac{s 1^{2}}{n 1}+\frac{s 2^{2}}{n 2}}
$$

d. Kriteria pengujian adalah sebagai berikut:

1) Jika nilai $\mathrm{z}$ hitung $>\mathrm{z}$ tabel

2) Berarti $H_{a}$ diterima dan $H_{0}$ ditolak, artinya bahwa secara statistik biaya, penerimaan, keuntungan dan risiko usaha rumput laut teknik budidaya terdapat perbedaan yang nyata dengan biaya, penerimaan, keuntungan dan risiko usaha rumput laut dengan alat pukat.

3) Jika nilai $\mathrm{z}$ hitung $<\mathrm{z}$ tabel:

4) Berarti $H_{o}$ diterima dan $H_{a}$ ditolak artinya bahwa secara statistik biaya, penerimaan, keuntungan dan risiko usaha rumput laut teknik budidaya tidak terdapat perbedaan yang nyata.

\section{2) Analisis Risiko}

Pengukuran risiko dapat menggunakan analisis koefisien variasi dimana dalam perhitungan terlebih dahulu menghitung nilai variasi dan standar deviasi. Dalam perhitungannya dapat menganalisisnya di Microsoft Excel dengan analisis z test two sample for mean.Selanjutnya resiko fisik dan resiko sosial digambarkan dengan analisis deskriptif. 
1. Ragam dapat di hitung dengan rumus:

Keterangan:

$$
\mathrm{Va}^{2}=\frac{\sum\left(\mathrm{Q}-\mathrm{Q}_{1}\right)^{2}}{\mathrm{n}-1}
$$

$\mathrm{Va}_{2}=$ Ragam (variance)

$\mathrm{Q}=$ Hasil biaya, Penerimaan, Keuntungan

Usahatani Rumput Laut

$\mathrm{Q}_{1}=$ Hasil Biaya Rata-rata, Penerimaan

Rata-rata, Keuntungan Rata-rata.

$\mathrm{n} \quad=$ Jumlah Sampel

2. Simpangan baku (standar deviation) dapat dihitung dengan rumus:

Keterangan:

$\mathrm{Va}=$ Simpangan Baku

$\mathrm{Va}^{2} \quad=$ Ragam (variance)

3. Koefisien Variasi

Tentang ada tidaknya risiko dapat diukur dengan koefisien variasi, dimana semakin kecil nilai koefisian variasi maka semakin kecil risiko yang dihadapi. Sebaliknya semakin besar nilai koefisien variasi maka semakin besar risiko yang dihadapi. Adapun rumuss dalam menghitung koefisien variasi utuk menjawab tujuan kedua menurut Kurniati (2011) adalah sebagai berikut:

Risiko biaya :

$$
\mathrm{CV}=\frac{\sigma \mathrm{c}}{\mathrm{Cr}}
$$

Risiko penerimaan
\[ \mathrm{CV}=\frac{\sigma \mathrm{r}}{\mathrm{Rr}} \]

Risiko keuntungan

$$
\mathrm{CV}=\frac{\sigma \mathrm{y}}{\mathrm{Yr}}
$$

Keterangan :

$$
\begin{array}{ll}
\mathrm{CV} & =\text { Koefisien Variasi } \\
\sigma \mathrm{c} & =\text { Standar Deviasi Biaya } \\
\sigma \mathrm{r} & =\text { Standar Deviasi Penerimaan } \\
\sigma \mathrm{y} & =\text { StandarDeviasi Keuntungan } \\
\mathrm{Cr} & =\text { Nilai Rata-rata Biaya } \\
\mathrm{Rr} & =\text { Nilai Rata-rata Penerimaan } \\
\mathrm{Yr} & =\text { Nilai Rata-rata Keuntungan }
\end{array}
$$

\section{HASIL DAN PEMBAHASAN}

Luas lahan dan Panjang Bentangan Petani Rumput Laut Teknik Budidaya dan Alat Pukat

Luas lahan dan luas bentangan merupakan salah satu faktor penentu berjalan atau tidaknya usahatani rumput laut. Dalamusaha rumput laut teknik budidaya, luas lahan yang di maksud adalah luas wilayah permukaan laut yang digunakan sebagai lahan usahatani rumput laut, sedangkan dalam teknik pukat adalah panjang bentangan di wilayah permukaan laut yang digunakan sebagai lahan untuk mejaring rumput laut.

Analisis Perbandingan Tingkat Biaya, Penerimaan, Dan Keuntungan Petani Usaha Rumput Laut Antara Teknik Budidaya Dan

\begin{tabular}{|c|c|c|c|c|}
\hline \multirow{3}{*}{$\begin{array}{l}\text { Uraian } \\
\text { Perbandinga } \\
\text { n Biaya, } \\
\text { Penerimaan, } \\
\text { dan } \\
\text { Keuntungan } \\
\end{array}$} & \multicolumn{4}{|c|}{ Usahatani Rumput Laut } \\
\hline & \multirow[t]{2}{*}{$\begin{array}{l}\text { Teknik } \\
\text { Budidaya } \\
\end{array}$} & \multicolumn{2}{|c|}{$\begin{array}{l}\text { Teknik } \\
\text { Pukat }\end{array}$} & \multirow{2}{*}{$\begin{array}{l}Z \\
\text { Hitung }\end{array}$} \\
\hline & & & & \\
\hline Biaya & (Rp) & $(\mathrm{Rp})$ & & $-9,18 * *$ \\
\hline Uraian & \multicolumn{4}{|c|}{ Usaha Rumput Laut } \\
\hline & \multicolumn{2}{|c|}{ Teknik Budidaya } & \multicolumn{2}{|c|}{ Teknik Pukat } \\
\hline $\begin{array}{l}\text { Luas Lahan } \\
\left(\mathrm{m}^{2}\right)\end{array}$ & $5.215,90$ & & - & \\
\hline $\begin{array}{l}\text { Luas } \\
\text { Bentangan }\left(\mathrm{m}^{2}\right)\end{array}$ & - & \multicolumn{3}{|c|}{488,39} \\
\hline 1. Biaya & \\
\hline Variabel & \multirow{2}{*}{\multicolumn{4}{|c|}{2.665 .909}} \\
\hline Bibit & & & & \\
\hline $\begin{array}{c}\text { Tali } \\
\text { Rafia } \\
\text { Tenaga }\end{array}$ & \multirow[t]{2}{*}{10} & \multicolumn{3}{|l|}{10} \\
\hline $\begin{array}{l}\text { Kerja: } \\
\quad \text { a.Tenaga }\end{array}$ & & & & \\
\hline $\begin{array}{l}\text { Kerja Dalam } \\
\text { Keluarga } \\
\text { b. }\end{array}$ & 3.812 .727 & 1.128 & 182 & \\
\hline $\begin{array}{l}\text { Tenaga } \\
\text { Kerja Luar }\end{array}$ & 558.333 & 3.091 & 515 & \\
\hline & $\begin{array}{l}4.371 .061 \\
(7.046 .970 \\
)\end{array}$ & \multicolumn{2}{|c|}{4.219 .697} & (4.229.696) \\
\hline \multicolumn{5}{|l|}{$\begin{array}{l}\text { 2. Biaya } \\
\text { Tetap }\end{array}$} \\
\hline $\begin{array}{c}\text { Sewa } \\
\text { Penjemuran }\end{array}$ & 1.007 .575 & \multicolumn{3}{|c|}{3.011 .969} \\
\hline $\begin{array}{c}\text { Biaya } \\
\text { Perawatan }\end{array}$ & 262.121 & 500 & & \\
\hline $\begin{array}{c}\text { Biaya } \\
\text { Penyusutan }\end{array}$ & 3.128 .960 & 13.10 & 2.269 & \\
\hline
\end{tabular}
Teknik Alat Pukat selama 2 bulan produksi

Dalam perhitungannya perbandingan tingkat biaya, penerimaan, dan keuntungan usaha rumput laut masing-masing teknik di Kelurahan Pantai Amal dapat dilihat pada tabel 1 berikut ini.

Tabel 1. Analisis Perbandingan Tingkat Biaya, Penerimaan, Dan Keuntungan Petani Usaha Rumput Laut Antara Teknik Budidaya Dan Teknik Alat Pukat selama 2 bulan produksi 


$\begin{array}{llll} & (4.398 .657 & (16.614 .239 & \\ & ) & ) & \\ \text { Produksi } & 1.015,15 & 2.969,54 & \\ \text { Harga } & 14.864 & 13.912 & \\ \text { Penerimaan } & 15.018 .181 & 41.996 .212 & \text { 14,14* } \\ \text { Keuntungan } & 3.572 .555 & 21.152 .276 & -6,78^{* *}\end{array}$

(Sumber: Data Primer diolah, 2020)

\section{Biaya Usaha Rumput Laut Antara Teknik Budidaya Dan Teknik Alat Pukat selama 2 bulan produksi}

1. Biaya Investasi

Biaya investasi dalam usahatani rumput laut meliputi sarana prasarana dimana dalam teknik budidaya antara lain perahu,mesin, tali ris, tali cincin, jerigen, pukat, penjemuran, dari, terpal, dan kayu pancang. Sedangkan dalam teknik pukat meliputi perahu, mesin, kayu pancang, penjemuran,dari, terpal, dan pukat.

Tabel 2. Rata-Rata Biaya Investasi Usahatani Rumput Laut Teknik Budidaya Dan Teknik Pukat

\begin{tabular}{clrrcr}
\hline No & $\begin{array}{c}\text { Jenis } \\
\text { Investasi }\end{array}$ & \multicolumn{2}{c}{ Teknik Budidaya } & \multicolumn{2}{c}{ Teknik Pukat } \\
& & \multicolumn{1}{c}{$(\mathrm{Rp})$} & $(\%)$ & \multicolumn{1}{c}{$(\mathrm{Rp})$} & $(\%)$ \\
1 & Perahu & 19.060 .606 & 37 & 22.000 .000 & 34 \\
2 & Mesin & 24.848 .485 & 49 & 21.287 .878 & 33 \\
3 & Tali Ris & 3.101 .818 & 6 & & \\
4 & Tali Cincin & 175.818 & & & \\
5 & Botol & 1.863 .636 & 4 & & \\
6 & Jerigen & 165.909 & 0 & & \\
7 & Pukat & & & 15.351 .515 & 24 \\
8 & Kayu & 32.707 & 0 & 2.380 .606 & 4 \\
& Pancang & & & & \\
9 & Penjemuran & 1.007 .575 & 2 & 3.011 .969 & 5 \\
10 & Dari & 512.121 & 1 & 518.182 & 1 \\
11 & Terpal & 350.000 & 1 & 572.606 & 1 \\
\hline & Total & 51.186 .675 & 100 & 65.122 .756 & 100 \\
\hline
\end{tabular}

(Sumber : Data primer diolah, 2020)

Biaya investasi rata-rata yang dikeluarkan dalam kegiatan usahatani teknik budidaya dan teknik pukat adalah masing-masing sebesar $\mathrm{Rp}$ 51.186.675 dan Rp 65.122.756.

2. Biaya variabel (variable cost)

Biaya variabel (VC) yang di butuhkan petani rumput laut di Kelurahan Pantai Amal adalah biaya yang habis terpakai dalam satu kali produksi rumput laut. Dalam hal ini biaya variabel teknik budidaya adalah biaya pembelian bibit basah dan tali rafia sedangkan untuk teknik pukat yaitu biaya tali rafia. Bibit rumput laut menjadi biaya variabel dikarenakan dalam pemanfaatannya petani membelinya saat pertama kali melakukan usaha budidaya. Ketika bibit rumput laut berkembang cukup baik tanpa terkena hama/penyakit maka petani akan menyisihkan bibit rumput laut itu untuk masa penanaman selanjutnya sehingga petani tidak membeli lagi. Berdasarkan tabel 7, rata-rata biaya variabel yang dikeluarkan petani rumput laut antara teknik budidaya dan teknik pukat rata-rata sebesar Rp. 7.046.970 dan 4.229.697.

Dalam perhitungan biaya tenaga kerja di daerah penelitian, dihitung dengan curahan tenaga kerja pria dan wanita dalam satu hari. Curahan tenaga kerja merupakan banyaknya penggunaan tenaga kerja yang dipergunakan oleh responden pada satu usaha supaya dapat memberikan hasil berupa pendapatan. Rata-rata upah tenaga kerja yang di nilai dalam bentuk uang adalah Rp.100.000.Pemakaian ukuran jam kerja dianggap dapat memenuhi keperluan, tanpa memperhatikan kebiasaan kerja yaitu delapan jam kerja dalam satu hari kerja.

3. Biaya Tetap (Fixed cost) Petani Rumput Laut Dalam Satu Kali Produksi

Biaya tetap (FC) yang dimaksud dalam penelitian ini adalah biaya yang tidak habis dalam satu kali produksi tetapi hanya mengalami penyusutan atau disebut sebagai biaya investasi. Metode yang digunakan peneliti adalah metode garis lurus. Berdasarkan pendapat yang dikemukakan oleh Firnawati (2016) bahwa metode garis lurus mempunyai beberapa kelebihan yaitu mudah digunakan dalam praktek dan lebih mudah dalam menentukan tarif penyusutan. Sedangkan kelemahan dari metode garis lurus adalah beban pemeliharaan dan perbaikan dianggap sama setiap periode, manfaat ekonomis barang setiap tahun sama. Biaya tetap yang dihitung penyusutannya dalam penelitian ini adalah biaya sewa penjemuran, biaya perawatan, serta biaya penyusutan. Dalam teknik budidaya biaya penyusutan yang dihitung meliputi tali ris, mesin, perahu, jergen, botol, pisau, terpal, dari, tali pengikat bibit/tali cincin, sedangkan dalam teknik pukat meliputi kayu pancang, pukat, perahu, mesin, sajau, dari, terpal, benang pukat.

Berdasarkan tabel 7, Besarnya rata-rata total biaya tetap yang dikeluarkan dalam kegiatan usaha rumput laut teknik budidaya dan teknik pukat adalah Rp 4.398.657 dan Rp 16.614.239. Dalam biaya tetap dapat dilihat bahwa besarnya biaya tetap dalam usaha rumput laut adalah teknik pukat.

\section{Penerimaan}

Penerimaan atau pendapatan kotor adalah seluruh pendapatan yang diperoleh dari usahatani selama satu periode diperhitungkan dari hasil 
penjualan. Berdasarkan hasil penelitian, penerimaan yang diterima usahatani rumput laut dalam satu kali produksi merupakan hasil dari banyaknya hasil produksi yang diperoleh petani rumput laut di kalikan harga.

Teknik budidaya rumput laut memerlukan waktu \pm 45 hari atau 2 bulan untuk memproduksi rumput laut, sedangkan dalam teknik pukat, para petani dapat menghasilkan/memproduksi rumput laut dari hasil tangkapan mereka setiap hari. Mereka menjaring rumput laut maksimal 15 hari yang bergantung pada pasang surutnya air laut, sehingga jika dibandingkan masa produksi rumput laut teknik budidaya yang hampir 2 bulan, petani rumput laut yang menggunakan teknik pukat dapat menghasilkan 4 kali produksi dalam periode 2 bulan.

Berdasarkan tabel 1 , besarnya penerimaan rata-rata yang didapatkan pada kegiatan usaha rumput laut teknik budidaya dan teknik pukat adalah masing-masing sebesar Rp 15.018.181 dan Rp 41.996.212. Hal ini menunjukkan bahwa usaha rumput laut teknik pukat memiliki penerimaan tertinggi dibandingkan dengan teknik budidaya. Berbeda dengan penelitian Nurmila (2019) menunjukkan bahwa penerimaan rata-rata petani rumput laut teknik budidaya rata-rata sebesar Rp.18.692.748.

\section{Keuntungan}

Keuntungan kegiatan usaha rumput laut di Kelurahan Pantai Amal diperoleh dari selisih antara total penerimaan dengan total biaya (biaya eksplisit dan implisit) yang dikeluarkan pada saat melakukan kegiatan usaha rumput laut.

Berdasarkan tabel 1 menunjukkan bahwa keuntungan usaha rumput laut teknik pukat lebih besar dibanding dengan keuntungan usaha rumput laut teknik budidaya. Hasil perhitungan $\mathrm{z}$ tes pada tabel 1 menunjukkan bahwa biaya, penerimaan, dan keuntungan usaha rumput laut teknik pukat terdapat perbedaan yang nyata dengan biaya, penerimaan, dan keuntungan usaha rumput laut teknik budidaya di kelurahan Pantai Amal karena nilai z hitungnya lebih besar dari z tabel yaitu 1,95.

\section{Analisis Perbandingan Risiko Biaya,Risiko Penerimaan, dan Risiko Keuntungan Teknik Budidaya dan Teknik Pukat di Kelurahan Pantai Amal}

\section{Risiko Ekonomi}

Risiko ekonomi merupakan suatu keadaan dimana terjadi perubahan drastis dalam lingkungan bisnis yang juga mempengaruhi keuntungan dan tujuan usahanya. Dalam penelitian ini, risiko ekonomi yang dimaksud adalah risiko biaya, risiko penerimaan, dan risiko keuntungan yang dianalisis menggunakan koefisien variasi (CV).

Tabel 3. Analisis Perbandingan Risiko Biaya, Risiko Penerimaan, dan Risiko Keuntungan Teknik Budidaya dan Teknik Pukat

\begin{tabular}{lccc}
\hline $\begin{array}{l}\text { Perbandingan } \\
\text { Risiko Biaya, }\end{array}$ & Teknik & Teknik & $\mathrm{Z}$ \\
$\begin{array}{l}\text { Penerimaan, } \\
\text { dan }\end{array}$ & Budidaya & Pukat & Hitung \\
Keuntungan & & & \\
\hline CV Biaya & 0,03 & 0,02 & 2.19 \\
CV Penerimaan & 0,05 & 0,05 & 0.15 \\
CV & 0,15 & 0,09 & 3.32 \\
Keuntungan & & &
\end{tabular}

(Sumber : Data Primer diolah, 2020)

a. Risiko Biaya

Berdasarkan tabel 10, risiko biaya teknik pukat lebih rendah dibandingkan teknik budidaya. Hal ini disebabkan oleh tingginya penggunaan variasi biaya teknik budidaya. Pada perhitungan uji z dengan $\mathrm{z}$ hitung 2,19, lebih besar dari $t$ tabel 1,95 yang menunjukkan bahwa risiko biaya usaha rumput laut teknik pukat terdapat perbedaan yang nyata dengan risiko biaya teknik budidaya. Risiko biaya usaha rumput laut teknik budidaya yang tinggi karena adanya kerusakan-kerusakan yang terjadi pada alatalat usaha, seperti tali ris, tali cincin, botol, maupun jergen yang harus diganti setiap kali produksi.Selain itu tingginya risiko terjadi serangan hama/ penyakit yang membuat rumput laut yang dibudidayakan gagal. Biaya dalam pembelian bibit rumput laut menyebabkan tingginya biaya yang dikeluarkan.

b. Risiko Penerimaan

Risiko penerimaan usaha rumput laut teknik budidaya memiliki risiko yang sama di bandingkan teknik pukat. Pada uji perbandingan (z-test), Uji statistik z-hitung $(0,15)$ lebih kecil dari t-tabel $(1,95)$. Dapat disimpulkan bahwa hipotesis ditolak yang menyatakan risiko penerimaan usaha rumput laut teknik pukat tidak terdapat perbedaan yang nyata dengan risiko penerimaan teknik budidaya.

Dalam penerimaan teknik budidaya maupun teknik pukat risiko penerimaan terjadi ketika rumput laut terkena serangan hama yang menyebabkan produksi menurun, harga ju al yang berfluktuasi, serta kualitas rumput laut. Kualitas rumput laut yang 
dimaksud di sini adalah hasil teknik budidaya memiliki kualitas yang lebih baik daripada teknik pukat. Berdasarkan hasil wawancara dengan petani di daerah penelitian, rumput laut hasil budidaya lebih berat dari pada hasil pukat. Hal ini dikarenakan umur panen teknik budidaya yang cukup, sedangkan dalam teknik pukat rumput laut yang diperoleh bermacam-macam, ada yang umurnya masih muda sampai tua sehingga ketika berada dalam tahap penjemuran rumput laut yang masih muda lebih cepat hancur dari pada rumput laut yang sudah cukup umur.

\section{c. Risiko Keuntungan}

Pada tabel 10 menunjukkan bahwa usaha rumput laut teknik budidaya memiliki risiko keuntungan yang tinggi dibandingkan dengan risiko usaha rumput laut teknik pukat, hal ini berarti variasi keuntungan teknik budidaya lebih tinggi. Resiko dapat berasal dari kegagalan panen karena serangan penyakit pada rumput laut, sehingga mengakibatkan kematian secara masif pada rumput laut yang dibudidayakan. Kegagalan kedua bisa datang dari pasar. Kondisi pasar yang tidak baik menjadi penyebab rendahnya harga jual rumput laut di pasaran, akibatnya penerimaan petani menjadi sangat rendah dan tidak mampu menutupi biaya produksi yang telah dikeluarkan.

Penerimaan teknik budidaya di daerah penelitian, hanya terjadi dalam satu sampai 2 kali kali produksi dalam waktu 2 bulan petani dapat panen. Sedangkan usaha rumput laut teknik pukat, penerimaannya dalam waktu 2 bulan bisa melakukan 4 kali produksi. Hal lainnya yaitu dalam kegiatan teknik pukat dilakukan setiap hari yang memungkinkan hasil rumput laut yang diperoleh besar, berbeda dengan petani teknik budidaya yang menunggu hasil produksi sampai 2 bulan. Pada uji perbandingan (t-test), Uji statistiK zhitung $(3,32)$ lebih besar dari t-tabel $(1,95)$. Dapat disimpulkan bahwa hipotesis diterima yang menyatakan keuntungan usaha rumput laut teknik pukat terdapat perbedaan yang nyata dengan keuntungan teknik budidaya.

\section{Risiko Fisik}

Dalam teknik budidaya dan pukat rumput laut, kondisi yang dapat menghambat rumput laut dalam perkembangannya adalah sebagai berikut :

1. Hama dan Penyakit

Jenis hama yang terdapat pada rumput laut di daerah Kelurahan Pantai Amal yaitu lumut, tiram yang sering melekat pada tali ris yang mengganggu proses budidaya, kutu-kutuan yang menempel pada rumput laut, ubur-ubur yang menghambat kegiatan control para petani rumput laut, serta alga yang menempel pada thallus dapat menyebabkan kematian secara perlahan-lahan karena dapat menghalangi rumput laut untuk memperoleh makanan atau cahaya matahari untuk melakukan fotosintesis, karena menempel erat pada thallus sehingga saat dibersihkan banyak thallus yang patah atau terluka (Tyani, 2015). Sedangkan untuk jenis penyakit yang sering di serang yaitu penyakit iceice/batang putih yang menyebabkan kerontokan pada rumput laut.

Sedangkan untuk teknik pukat, hama dan penyakit juga menjadi resiko dalam penjaringannya. Rumput laut yang di jaring memiliki jenis hama dan penyakit seperti dalam teknik budiidaya seperti lumut yang menyebabkan terjadinya penurunan produksi dan memicu terjadinya penurunan harga,

2. Kondisi iklim yang tidak mendukung.

Kegagalan panen petani rumput laut juga dipengaruhi oleh keadaan arus, curah hujan, sinar matahari, dan gelombang. Apabila arus dan gelombang kuat, maka kemungkinan besar rumput laut yang di tanam mengalami kerontokan karena tekanan besar yang terjadi di areal budidaya. Berbeda dengan pendapat Nontji (2013) bahwa arus merupakan gerakan mengalir oleh suatu massa air, terjadi akibat adanya faktor seperti tiupan angin, gerakan gelombang panjang, perubahan densitas air laut dan pasang surut. Tingkat kesuburan lokasi penanaman sangat ditentukan oleh adanya gerakan air (berombak dan arus).

Berbeda dengan teknik pukat, ketika arus dan gelombang kuat faktor inilah yang menyebabkan banyak rumput laut terjaring. Menurut Aslan (1991) bahwa meskipun rumput laut masih bisa tumbuh pada $40 \mathrm{~cm} / \mathrm{det}$ (Aslan, 1991), kecepatan arus sebesar itu dapat merusak konstruksi budidaya dan mematahkan percabangan rumput laut.

Faktor curah hujan dan cahaya matahari juga menjadi penentu dalam pertumbuhan rumput laut. Rumput laut akan mudah berkembang ketika mendapat pasokan air hujan dan matahari yang cukup. Ketika terjadi kemarau berkepanjangan maka rumput laut akan sulit berkembang dan menjadi kecil.

3. Limbah laut

Limbah laut menjadi permasalahan dalam pembudidayaan rumput laut. Berdasarkan penelitian, rumput laut petani budidaya sering 
terkena batang besar ketika terjadi hujan lebat dan longsor, yang menyebabkan pondasi atau areal lahan penanaman rusak dan akhirnya rumput laut juga ikut rusak. Hal ini menyebabkan rumput laut mengalami kerusakan dalam daerah budidaya.

\section{Risiko Sosial}

Sumber utama risiko ini adalah masyarakat. Artinya, tindakan orang-orang menciptakan kejadian yang menyebabkan penyimpangan merugikan. Misalnya; pencurian, vandalisme, huru-hara, peperangan dan sebagainya. Berdasarkan hasil penelitian di daerah Kelurahan Pantai Amal resiko sosial yang terjadi antara lain pencurian dan konflik antara petani budidaya dan pemukat.

\section{KESIMPULAN}

Berdasarkan hasil penelitian yang dilakukan di Kelurahan Pantai Amal Kota Tarakan, adapun kesimpulan yang dapat diberikan sebagai berikut:

a. Biaya, penerimaan, dan keuntungan usahatani rumput laut teknik alat pukat lebih besar dibandingkan dengan usahatani rumput laut teknik budidaya dengan biaya masing-masing sebesar Rp 20.843.936 dan Rp11.445.627, penerimaan masing- masing sebesar Rp41.996.212 dan Rp15.018.181, sedangkan keuntungan masing-masing sebesar Rp21.152.276 dan Rp 3.572.555. Perhitungan statistik menunjukkan bahwa biaya, penerimaan, dan keuntungan terdapat perbedaan yang nyata antara usahatani rumput laut teknik budidaya dan alat pukat di Kelurahan Pantai Amal.

b. Usaha rumput laut teknik pukat memiliki risiko biaya dan risiko keuntungan lebih rendah dibandingkan dengan usaha rumput laut teknik budidaya dengan besar nilai koefisien variasi (CV) masing-masing sebesar 0,02 dan 0,03, risiko penerimaan usahatani rumput laut teknik pukat dan teknik budidaya sama yaitu 0,05 , untuk risiko keuntungan usaha rumput laut teknik budidaya lebih tinggi daripada teknik pukat yaitu masing-masing 0,15 dan 0,09 . Risiko biaya dan keuntungan usaha rumput laut teknik alat pukat lebih kecil dibanding dengan teknik budidaya, pada perhitungan statistik juga terdapat perbedaan yang nyata antara nilai risiko biaya dan risiko keuntungan di antara keduanya. Namun berbeda dengan perhitungan statistik risiko penerimaan dimana tidak terdapat perbedaan nyata. Adapun risiko fisik antara lain Selain risiko ekonomi, terdapat juga risiko fisik antara lain hama dan penyakit, kondisi iklim yang tidak mendukung, dan limbah laut. Serta risiko sosial antara lain pencurian dan konflik kepentingan yang mempengaruhi keuntungan petani rumput laut.

\section{UCAPAN TERIMA KASIH}

Alhamdulillahirabbil'alaimin, Puji syukur penulis panjatkan kepada Tuhan Yang Maha Esa atas segala karunia-Nya sehingga penulis dapat menyelesaikan artikel ini yang berjudul "(Analisis Perbandingan Keuntungan Dan Risiko Agribisnis Rumput Laut (Eucheuma Cottonii) Dengan Menggunakan Teknik Budidaya Dan Alat Pukat Di Kelurahan Pantai Amal Kota Tarakan)." Penulis menyadari bahwa dalam penulisan artikel ini masih banyak kekurangan. Oleh karena itu, penulis mengharapkan kritik dan saran yang bersifat membangun yang digunakan sebagai tambahan informasi bagi semua pihak yang membutuhkan. Penulis mengucapkan banyak terima kasih kepada semuanya dan semoga kita selalu di rahmati Allah SWT, aamiin.

\section{DAFTAR PUSTAKA}

Ardiansyah, Nurjannatul. (2019). Analisis Kebijakan, Strategi dan Analisis SWOT Pengelolaan Usaha Rumput Laut Nelayan Daerah Pesisir Pantai Amal Kota Tarakan. Jurnal Metris 19 : 131138.

Aslan, M.L.( 2008). Rumput Laut. Cetakan VII. KANISIUS, Yogyakarta.

Aziz, N. (2003). Pengantar Mikro ekonomi. Aplikasi dan Manajemen. Banyumedia Publishing, Malang.

Bambang R.R. (2017). Manajemen Risiko. Salemba Empat, Jakarta

BPS Kota Tarakan. 2018. tarakan kota.bps.go.id. diakses pada tanggal 1 Januari 2020. Badan Pusat Statistik Kota Tarakan.

DPPP (2019). Data Pemasaran dan Produksi Rumput Laut Kering Kota Tarakan, Provinsi Kalimantan Utara. Leaflet. Dinas Pangan, Pertanian, dan Perikanan Kota Tarakan.

Fitrinawati. (2016). Analisis Biaya Produksi dan Pendapatan Usahatani Rumput Laut Di Desa Ollo Selatan Kecamatan Kaledupa 
$\begin{array}{ll}\text { Kabupaten } & \text { Wakatobi.[Skripsi]. } \\ \text { Universitas Haluleo, } & \text { Kota } \\ \text { Kendari.[Indonesia]. } & \end{array}$ Farionita, et all. (2018). Analisis Komparatif Usaha Budidaya Udang Vaname Tambak Tradisional Dengan Tambak Intensif Di Kabupaten Situbondo. Jurnal Ekonomi Pertanian dan Agribisnis (JEPA). 2 (4) : 256-266.

Fidyansari, Wildana. (2015). Analisis Perbandingan Usahatani Rumput Laut antara Sistem Integrasi Ikan Bandeng dan Tanpa Ikan Bandeng di Kelurahan Balandai Kecamatan Bara Kota palopo.[Skripsi].Universitas

Cokroaminoto Palopo, Kota Palopo. [Indonesia].

Hery .2019. Manajemen Resiko Bisnis. PT Grasindo, Jakarta.

Husain, 2016. Analisis Perbandingan Keuntungan Dan Risiko Usaha Perikanan Rakyat Sistem Monokultur Dan Polikultur Di Kabupaten Pangkep. Jurnal Agro Ekonomi 27 ( 2) : 16-29.

Inge Mayusi Farionita. 2018. Analisis Komparatif Usaha Budidaya Udang Vaname Tambak Tradisional dengan Tambak Intensi di Kabupaten Situbondo.[ Skripsi]. Universitas Jember, Kota Jember. [Indonesia].

Rahim, A. R. (2018). Application of Seaweed Gracilaria verrucosa Tissue Culture using Different Doses of Vermicompost Fertilizer. Nature Environment and Pollution Technology, 17(2) : 661-665.

Sugiyono. (2011). Metode Penelitian Kuantitatif Kualitatif dan R\&D. Alfabeta, Bandung. Ken Suratiyah. 2015. Ilmu Usahatani. Penebar Swadaya, Jakarta. 